\title{
Macroeconomic Factors and Corporate Capital Structure: Evidence from Listed Joint Stock Companies in Vietnam
}

\author{
Phan Thi Quoc Huong ${ }^{1}$ \\ ${ }^{1}$ Faculty of Finance - Banking and Business Administration, Quy Nhon University, Vietnam \\ Correspondence: Phan Thi Quoc Huong, Faculty of Finance, Banking and Business Administration, Quy Nhon \\ University, Vietnam.
}

Received: October 16, 2017

Accepted: November 11, 2017

Online Published: November 30, 2017

doi:10.5430/ijfr.v9n1p31

URL: https://doi.org/10.5430/ijfr.v9n1p31

\begin{abstract}
This study is conducted to examine how macro determinants affect capital structure of non-financial joint stock companies in Vietnam. The two-step system GMM is used to analyze data which is a combination of two sources: financial statements of 464 listed joint stock companies on 3 main stock exchanges (HOSE, HNX, and UPCOM), and World Bank database in the period of 2008-2015. The findings show that firms' capital structure decisions are impacted by elements which reflect macroeconomic conditions. In detail, the inflation rate has positive influence while corporate income tax rate is on the contrary. Besides, the affectation of financial development and institutional quality on capital structure of these enterprises is found clearly. Not only macro factors, this research explores but also other determinants which are characteristics company such as size, profitability, and payment capacity. Finally, it is noticeable that capital structure decisions depend on capital structure of the previous year.
\end{abstract}

Keywords: macro determinant, capital structure, joint stock company, GMM

\section{Introduction}

Structuring capital is one of the most important decisions of corporate financial officers. Choosing the appropriated proportion of each funding sources to form the optimal capital structure in order to minimize capital cost, minimize risk and maximize corporate value was the goal which most of the administrators want to achieve. Finding an optimal capital structure and influencing factors is not only a top concern of financial managers but also a topic that attracts a large number of theoretical and empirical researches in the world. The pioneering theory about the capital structure was found out nearly 70 years ago by Modigliani \& Miller's $(1958,1963)$ (referred as M \& M theories). Then, it was further developed by many following theories such as the Trade-off theory of capital structure (Kraus and Litzenberger, 1973); the Pecking order theory (Myers, 1984; Myers and Majluf, 1984); the Agency costs theory (Jensen and Meckling, 1976); the Market timing theory (Graham and Harvey, 2001). In parallel with these theories, the explorations from the empirical studies proved that the decision to choose a capital structure was affected by factors that reflected the company's unique characteristics, such as size, profitability, opportunity for growth, tangible assets, liquidity, risks of bankruptcy... (Titman and Wessels, 1988; Rajan and Zingales, 1995; Wald, 1999; Michaelas et al., 1999; Booth et al., 2001; Deesomsak et al., 2004; Chakraborty, 2010; Handoo and Sharma, 2014). Moreover, many recent studies have examined the impact not only of the company's characteristics but also of factors which reflected the government policies, law, macroeconomic status or financial development of the host country where the firm operated (Bokpin, 2009; Bostos et al., 2009; Kayo and Kimura, 2011; Camara, 2012; Mokhova and Zinecker, 2014; Memon et al., 2015; Temimi et al., 2016; Belkhir et al., 2016).

For Viet Nam, a number of studies were conducted to point out which elements affected the capital structure of listed companies. It is the fact that most of the researches focused on determinants related to the firms' characteristics (Biger et al., 2008; Phan Thi Bich Nguyet, 2011; Nguyen Thi Canh and Nguyen Thanh Cuong, 2011; Le Dat Chi, 2013; Vu Thi Ngoc Lan and Nguyen Tien Dung, 2013; Pham Tien Minh and Nguyen Tien Dung, 2015; Nguyen Thanh Cuong and Nguyen Hong Thang, 2015; Truong Hong Trinh and Nguyen Thao Phuong, 2016; etc). Only a few studies mentioned the macroeconomic factors which affected the capital structure of corporations in Vietnam, typically the study by Dang Thi Quynh Anh and Quach Thi Hai Yen (2014), Vo Thi Thuy Anh et al. (2014). It is worth mentioning that the identification of influencing elements in these studies was based on static capital structure; whereas several recent findings from Yang et al. (2015), Temimi et al. (2016), Belkhir et al. (2016) showed that the dynamic capital structure would be more appropriate when considering the impact of macro factors on the capital structure of firms. Besides, these papers tilted in favour of macroeconomy and financial development, and no studies 
have addressed the affectation of institutional quality on capital structure decisions of Vietnamese firms. Thus, this study was conducted to examine the impact of macro factors on the capital structure of listed joint stock companies in Vietnam through dynamic capital structure. Namely, the elements concerning macroeconomic conditions (corporate income tax rates, inflation rates, economic growth, and interest rates); financial development (based on three indicators: operation, size, and effectiveness of financial market); and the institutional quality (based on three indicators: Control of Corruption, Regulatory Quality, and Rule of Law).

The rest of the paper is structured as follows: section 2 presents literature review. Section 3 shows hypotheses and research model. Section 4 mentions research data and methodology. The two remaining sections reveal results and conclusions.

\section{Literature Review}

The theorem about optimal capital structure (M\&M theory) was first found by Modigliani and Miller (1958). They stated that the value of a company did not depend on its financial system in competitive capital markets without bankruptcy costs, corporate income tax or other market hazards. It was also recognized in 1963 that the value of a levered firm was equal to the value of an unlevered firm plus the present value of the "tax shield" when Modigliani and Miller assumed the corporate income tax. Although the M\&M theory considered the advantages of the tax shield, the argument about maximizing debt ratio to benefit from tax shield was not appropriate. This is because it did not care about the bankruptcy costs, the asymmetric information as well as the agency cost that might occur when lending. These major limitations of M\&M theory put the foundation for the development of modern capital structure theories.

Unlike M\&M theory, the trade-off theory, which was supported by Kraus \& Litzenberger (1973), suggested that optimal capital structure could be visualized as a balance between the costs and benefits of borrowing. A company would borrow until the marginal benefit of the tax reduction (tax shield from the debts) was equal to the increase in the present value of the bankruptcy costs.

Another view was developed by Myers (1984), Myers and Majluf (1984) when they researched the asymmetric information that existed between managers, shareholders, and investors. It was called the pecking order theory. This theory pointed out that the companies would like to fund themselves firstly with internal resources, then with loans, and eventually with the equities provided by shareholders.

In terms of expense which company spends, Jensen and Meckling (1976) developed a principal called the Agency cost theory. They cared about the costs that derived from the conflicts of benefits between the shareholders and the managers which occurred due to disagreements over executive decisions. Concurrently, these costs were related to the clash between shareholders and creditors when the company's debt increased and shareowners received benefits in creditors' stead in case of bankruptcy.

Dissimilar to many authors, Graham and Harvey (2001) researched the capital structure from the external factors. They focussed the Market timing theory which had been strongly supported by many financial managers around the world. Although the optimal capital structure was not defined, the market timing theory found out some certain elements of capital market and macroeconomic conditions that might affect the capital structure of companies. Rely on information asymmetry, managers would lend if their stocks were undervalued by the investors, otherwise, they chose issuing shares.

In brief, capital structure theories have been built on the contribution of various assumptions to offer an explanation for the relationship between capital structure and firm performance through the connection between rate of return and risk, the link of benefit between the owner, the creditor and the managers in a company. Moreover, these theories aimed to explain the determinants that concerned the choice of companies' capital structure. Beside the capital structure theories, many empirical studies tried to examine what things had the impact on the decisions of choosing capital structure in a company. In general, most of the researches explored that those aspects included not only the factors that reflected companies' characteristics such as size, profitability, growth opportunities, tangible assets, solvency, bankruptcy risk, etc. (Titman and Wessels, 1988; Rajan and Zingales, 1995; Wald, 1999; Michaelas et al., 1999; Booth et al., 2001; Deesomsak et al., 2004; Jong et al., 2007; Chakraborty, 2010; Handoo and Sharma, 2014) but also macroeconomic conditions (such as corporate income tax rates, inflation rates, economic growth and interest rates (Booth et al., 2001; Deesomsak et al., 2004; Bokpin, 2009; Bostos et al., 2009; Frank and Goyal, 2009; Mokhova and Zinecker, 2014; Memon et al., 2015; Temimi et al., 2016; Belkhir et al., 2016)), as well as financial development (Booth et al., 2001; Deesomsak et al., 2004; Bokpin, 2009; Kayo and Kimura, 2011; Temimi et al., 2016; Belkhir et al., 2016), and institutional quality (Mokhova and Zinecker, 2014; Belkhir et al., 2016) of the host countries, where the companies were operating.

The business in Vietnam has flourished more strongly since the early 1990s when a great economic reform was conducted. From a centrally planned economy, Vietnam transformed into a market economy managed by the state in 
which the most favorable business environment for enterprises has created with all Government's effort. It is the fact that many corporate decisions, especially capital structure decisions, are based not only on the characteristics of the company but also on the volatility of the macroeconomic factors. In other words, business environment plays a crucial role in firm's performance. Indeed, using data from 180 non-financial corporations listed on the Ho Chi Minh City Stock Exchange (HOSE) between 2010 and 2013, Dang Thi Quynh Anh and Quach Thi Hai Yen (2014) proved that the effective corporate income tax affected the capital structure of firms. With longer research time, Vo Thi Thuy Anh et al. (2014) analyzed the data of 200 companies listed on the Vietnam securities market for 2005-2013. They revealed that along with corporate income tax, many factors like inflation, GDP growth, capital market conditions, and debt market conditions also had an impact on the capital structure of companies in Vietnam. In both of these studies, the authors researched a static capital structure through the fixed-effects estimation (FEM) and random-effects effects (REM) for panel data.

\section{Models}

Based on the theories and empirical studies of Ozkan (2001), Fama and French (2002), Kayhan and Titman (2007), Oztekin and Flannery (2012), Yang et al. (2015), Temimi et al. (2016), Belkhir et al. (2016), model which reveals determinants affecting the capital structure of listed joint stock companies in Vietnam is suggested as follows:

Model 1: $\quad \mathbf{D}_{\mathrm{i}, \mathrm{t}}=\mathbf{a}_{\mathbf{0}}+\mathbf{a}_{1} \cdot \mathbf{D}_{\mathrm{i}, \mathrm{t}-\mathbf{1}}+\mathbf{a}_{2} \cdot \mathbf{X}_{\mathrm{i}, \mathrm{t}}+\mathbf{a}_{3} \cdot \mathbf{Y}_{\mathbf{t}}+\boldsymbol{\varepsilon}_{\mathrm{i}, \mathrm{t}}$

Model 2: $\quad \mathbf{D}_{\mathrm{i}, \mathrm{t}}=\mathbf{b}_{\mathbf{0}}+\mathbf{b}_{\mathbf{1}} \cdot \mathbf{D}_{\mathrm{i}, \mathrm{t}-\mathbf{1}}+\mathbf{b}_{\mathbf{2}} \cdot \mathbf{X}_{\mathrm{i}, \mathrm{t}}+\mathbf{b}_{\mathbf{3}} \cdot \mathbf{F D}_{\mathbf{t}}+\boldsymbol{\alpha}_{\mathrm{i}, \mathrm{t}}$

Model 3: $\quad \mathbf{D}_{\mathrm{i}, \mathrm{t}}=\mathbf{c}_{\mathbf{0}}+\mathbf{c}_{1} \cdot \mathrm{D}_{\mathrm{i}, \mathrm{t}-\mathbf{1}}+\mathbf{c}_{2} \cdot \mathbf{X}_{\mathrm{i}, \mathrm{t}}+\mathbf{c}_{3} \cdot \mathrm{INSt}+\boldsymbol{\mu}_{\mathrm{i}, \mathrm{t}}$

In the models, the dependent variable $\left(\mathrm{D}_{\mathrm{i}, \mathrm{t}}\right)$ reflects the capital structure of listed joint stock companies in Vietnam. It is measured by three indicators: total debts/total assets (LEV), long-term debt/total assets (LTD), short-term debt/total assets (STD). This scale is used by Titman and Wessels (1988), Michaelas et al. (1999), Bastos et al. (2009), Mokhova and Zinecker (2014), Handoo and Sharma (2014).

As above review, capital structure is strongly affected by firm's characteristics. Thus, $\mathrm{X}_{\mathrm{i}, \mathrm{t}}$ is a group of dependent variables that reflected the company's characteristics, which include company size (SIZE, calculated by log of total assets), profitability (PROFIT, defined by the rate of profit before tax, interest, and depreciation to average total assets), growth opportunities (GROW, measured by the growth rate of total assets), tangible assets (TANG, determined by the share of fixed assets to total assets), liquidity (LIQUID, described by the ratio of current assets to current liabilities), risk of bankruptcy (RISK, be the percentage of standard deviation of profit before tax and interest to total assets). Those scales are approached by Titman and Wessels (1988), Rajan and Zingales (1995), Wald (1999), Michaelas et al. (1999), Booth et al. (2001), Deesomsak et al. (2004), Chakraborty (2010), Handoo and Sharma (2014).

Moreover, each group of macro factors will be added in turn to the model with the aim of analyzing the influence of these external things. They consist of the groups of elements that reflect the macroeconomic conditions $\left(\mathrm{Y}_{\mathrm{t}}\right)$, the financial development $\left(\mathrm{FD}_{\mathrm{t}}\right)$, and the institutional quality $\left(\mathrm{INS}_{\mathrm{t}}\right)$ in model 1,2 , and 3 respectively. Firstly, the following items are used to illustrate macroeconomic conditions: corporate income tax (TAX), described by corporate income tax to profit before tax (Bostos et al., 2009; Handoo and Sharma, 2014; Belkhir et al., 2016); inflation rate (INF), calculated by the annual increase in consumer price index (Frank and Goyal, 2009; Bokpin, 2009; Memo et al., 2015; Yang et al., 2015; Temimi et al., 2016; Belkhir et al., 2016); economic growth (GDPG), defined by growth rate of real GDP (Camara, 2012; Belkhir et al., 2016); and interest rate (IR), measured by lending interest rate (Deesomsak et al., 2004; Memon et al., 2015). The second group which reflects the financial development of a country (FD) is based on studies of Belkhir et al. (2016), Tema et al. (2016). The detail independent variables in this group include FD1 (financial activity), FD2 (financial size), FD3 (financial efficiency). Financial activity, financial size, and financial efficiency are the measure of the activity, size, and efficiency of stock markets relative to that of banks. The two former are calculated by the logarithm of the total value traded ratio times the private credit ratio and the logarithm of the market capitalization ratio times the private credit ratio whereas the latter is the logarithm of the total value traded ratio divided by overhead costs. Next, on the basis of Belkhir et al. (2016), institutional quality (INS) is defined through three indicators: CORR - logarithm of the control of corruption; REGUL - logarithm of the regulatory quality; LAW - logarithm of rule of law. Those indicators are retrieved from Government Indicators of World Bank. Finally, the one-lagged of the dependent variables $\left(\mathrm{D}_{\mathrm{i}, \mathrm{t}-\mathrm{l}}\right)$ is also considered as an independent variable in the model; therefore, the capital structure decision of a company will depend on its value itself of the previous year.

\section{Data and Methodology}

\subsection{Data}

The data in this paper are assembled from two sources including financial statements of Vietnamese companies and 
database of World Bank. In detail, information about characteristics of the company is retrieved from financial statements of 464 non-financial listed joint stock companies on the three main stock exchanges in Vietnam (HOSE, HNX, and UPCOM) during the period 2008 to 2015. Data of macroeconomic conditions, financial development, and institutional quality of Vietnam from 2008 to 2015 are collected from the World Development Indicators database, the Financial Structure database, and Government Indicators database of the World Bank respectively.

\subsection{Methodology}

It is noticeable that the one-lagged of the independent variable $\left(\mathrm{D}_{\mathrm{i}, \mathrm{t}-1}\right)$ plays a role as an independent variable in the model; thus, this is dynamic panel data regression model in theoretical background terms. Using this type of model can bring some violations such as (1) capital structure variable goes endogenous because of the correlation between the one-lagged capital structure $\left(\mathrm{D}_{\mathrm{i}, t-1}\right)$ and the residual in model; (2) The one-lagged variable of dependent variable makes the one-level autocorrelation in the models; (3) the fixed effect in models' residual can exist because several features of companies which do not change over time (e.g. field of business) can be correlated with explanatory variables; (4) Research data has short time (time $-\mathrm{T}=8$ ) and large scope of space (quantity of companies $-\mathrm{N}=464$ ). To tackle the above mistakes, Difference Generalized method of moments (GMM), mentioned by Arellano and Bover (1991), Blundell and Bond (1998), is considered as the most suitable method to get unbiased, sustainable estimation results as well as reliable test results. Contemporaneously, Arellano-Bond test on autocorrelation at level 2 and Sargan test on exogenous instrumental variables will be employed to test the suitability of estimated results via GMM. After assessing test result by difference GMM and system GMM in all three models, Arellano-Bond test on autocorrelation test at level 2 and Sargan test on exogenous instrumental variables will be conducted. As a result, the two-step system GMM is confirm to be more suitable ( $\mathrm{P}_{\text {value }}$ in all cases are larger). Thus, this method is chosen to examine the effect of macro determinants of capital structure of listes joint stock companies in Vietnam.

\section{Results}

\subsection{Descriptive Statistics}

Table 1. Descriptive statistics

\begin{tabular}{lllllll} 
Variable & Units & Obs & Mean & Min & Max & Std. Dev. \\
\hline LEV & $(\%)$ & 3712 & 51.02 & 0.00 & 117.32 & 22.33 \\
\hline LTD & $(\%)$ & 3712 & 10.47 & 0.00 & 75.11 & 14.34 \\
\hline STD & $(\%)$ & 3712 & 40.55 & 0.00 & 98.78 & 21.07 \\
\hline SIZE & & 3712 & 26.84 & 20.97 & 32.62 & 1.41 \\
\hline PROFIT & $(\%)$ & 3712 & 13.31 & -144.67 & 179.18 & 16.94 \\
\hline GROW & $(\%)$ & 3712 & 167.44 & -99.70 & $165,535.00$ & $3,947.82$ \\
\hline TANG & $(\%)$ & 3712 & 27.07 & 0.00 & 97.79 & 21.54 \\
\hline LIQUID & $(\%)$ & 3712 & $1,370.77$ & 10.63 & $4,214,136.00$ & $69,165.70$ \\
\hline RISK & $(\%)$ & 3712 & 35.97 & 1.01 & 3706.74 & 106.53 \\
\hline TAX & $(\%)$ & 3712 & 18.64 & $1,478.02$ & $-2,382.48$ & -55.28 \\
\hline INF & $(\%)$ & 3712 & 9.80 & 0.88 & 23.12 & 6.96 \\
\hline GDPG & $(\%)$ & 3712 & 5.88 & 5.25 & 6.68 & 0.50 \\
\hline IR & $(\%)$ & 3712 & 11.95 & 7.12 & 16.95 & 3.23 \\
\hline FD1 & & 3712 & 0.10 & 0.03 & 0.17 & 0.04 \\
\hline FD2 & & 3712 & 0.21 & 0.12 & 0.25 & 0.04 \\
\hline FD3 & & 3712 & 14.78 & 0.00 & 30.93 & 9.65 \\
\hline CORR & $0-100$ & 3712 & 34.22 & 26.21 & 39.42 & 4.07 \\
\hline REGUL & $0-100$ & 3712 & 29.95 & 27.96 & 33.65 & 1.71 \\
\hline LAW & $0-100$ & 3712 & 40.50 & 34.60 & 46.15 & 3.36 \\
\hline
\end{tabular}

Source: calculated by the author 
Figures in Table 1 supply descriptive statistics about variables in three models. For the dependent variable which is the capital structure of listed joint stock firms in Vietnam, the average value in the period 2008-2015 of total debts rate (LEV), long-term debt rate (LTD), short-term debt rate (STD) were respectively $51.02 \%, 10.47 \%$, and $40.55 \%$. Hence, the capital structure of these corporations was debt-oriented mainly, in which a very high percentage belonged to short-term debt, at $79.48 \%$ of total debts.

For the independent variables that reflect firm characteristics, the statistical results show that the average value of logarithm of the companies' total assets (SIZE) was 26.84, which was in proportion to their average asset at VND 1,380 billion; The average of return on assets (PROFIT) accounted for $13.31 \%$; The average of potential growth (GROW) made up 167.44\%; The share of fixed asset to total assets (TANG) spent an average of 27.07\%; The percentage of short-term assets to short-term debt (LIQUID) was in average at 1,370.77\%; The average of business risk (RISK) amounted to $35.97 \%$.

In terms of independent variables illustrating the impact of macroeconomy, the effective corporate income tax rate of listed joint stock companies in Vietnam from 2008 until 2015 spent an average of 19.65\%. According to Vietnamese state regulations, along with current corporate income tax, the deferred income corporate tax will occur with what firms in priority. If the latter is bigger than the former, corporate income tax which the company has to pay will be positive. This is the reason why some cases whose effective corporate income tax is negative, e.g. this highest value in Table 1 accounts for -2,382.48, which Khang Dien House Trading and Investment JSC incurred in 2011. Furthermore, data which are assembled from World Bank (2017) shows that the average inflation rate in Vietnam was $9.8 \%$ over the period of 2008-2015, in which the highest and the lowest numbers were $23.12 \%$ in 2008 and $0.88 \%$ in 2015 in succession. The average, the highest, and the lowest real growth rate were 5.88\%, 6.68\% in 2015, and 5.25\% in 2012. The interest rate experienced an average of $11.95 \%$ while $16,95 \%$ in 2011 was the highest figure, and the adverse value was $7.12 \%$ in 2015 .

Regarding financial development, the average figures of financial activity, financial size, financial efficiency were $0.1,0.21$, and 14.78 respectively.

The proxies concerning institutional quality in Vietnam are measured with ratio scales from 0 to 100 . Then, the averages of control of corruption, regulatory quality, rule of law were in turn $34.22,29.95$, and 40.50 .

\subsection{Research Results}

As mentioned in literature review, six variables which describe firm's characteristics affect capital structure in most of studies. However, it is not clear on the impact of the business environment. So, in this paper, these six independent variables remain unchanged in the model, then we add each variable group of macro influence into the model gradually. There is a notice of simultaneous non-existence of all variables which reflect macro affectation in a model. It results from the perfect multicollinearity between those variables after testing Pearson autocorrelation coefficient and variance-inflation factor (VIF). Thus, the two-step process via GMM for each dependent variable (LEV, LTD, STD) which represents for capital structure will be carried out as follows.

(1) Regressing dependent variables on six independent variables which reflect company's characteristics (SIZE, PROFIT, GROW, TANG, LIQUID, RISK) and ones which describe macroeconomic conditions (TAX, INF, GDPG, IR);

(2) Regressing dependent variables on six independent variables which reflect company's characteristics and ones which describe financial development (FD1, FD2, and FD3);

(3) Regressing dependent variables on six independent variables which reflect company's characteristics and ones which describe institutional quality (CORR, REGUL, and LAW).

Table 2. Determinants of capital structure of non-financial joint stock companies in Vietnam (two-step system GMM)

\begin{tabular}{|c|c|c|c|c|c|c|c|c|c|}
\hline & LEV & & & LTD & & & STD & & \\
\hline & (1) & (2) & (3) & (1) & (2) & (3) & (1) & (2) & (3) \\
\hline \multirow[t]{2}{*}{ LEV (T-1) } & $0.941^{* * *}$ & $0.959^{* * *}$ & $0.961^{* * *}$ & & & & & & \\
\hline & $(0.000)$ & $(0.000)$ & $(0.000)$ & & & & & & \\
\hline \multirow[t]{2}{*}{ LTD (T-1) } & & & & $0.765^{* * *}$ & $0.749^{* * *}$ & $0.763^{* * *}$ & & & \\
\hline & & & & $(0.000)$ & $(0.000)$ & $(0.000)$ & & & \\
\hline
\end{tabular}




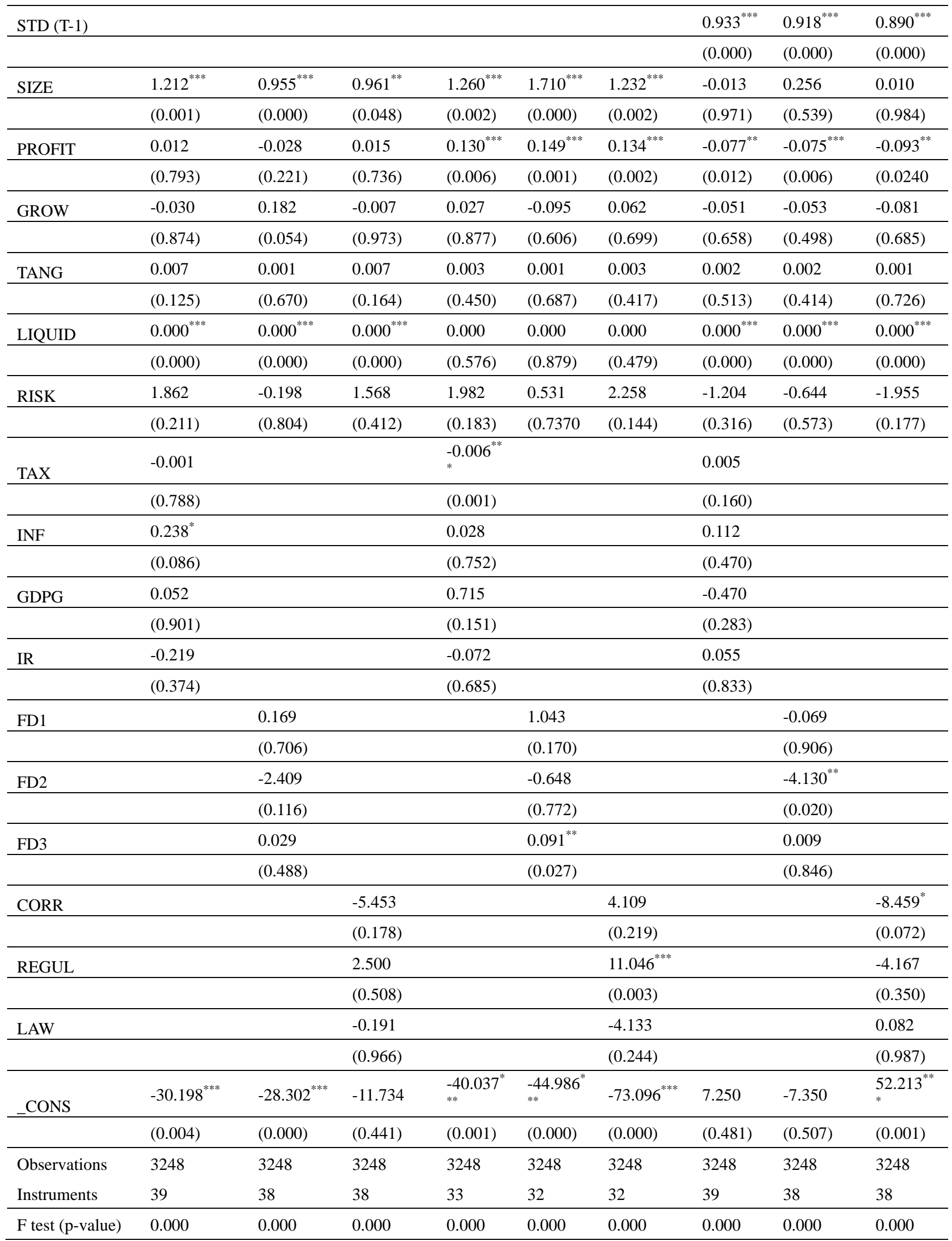




\begin{tabular}{lcccccccccc}
$\begin{array}{l}\text { AR(1) } \\
\text { (p-value) }\end{array}$ & test & 0.019 & 0.000 & 0.046 & 0.010 & 0.001 & 0.007 & 0.000 & 0.000 & 0.000 \\
\hline $\begin{array}{l}\text { AR(2) } \\
(\mathrm{p}-\text {-value) }\end{array}$ & test & 0.419 & 0.156 & 0.448 & 0.233 & 0.077 & 0.300 & 0.379 & 0.324 & 0.348 \\
\hline $\begin{array}{l}\text { AR(3) } \\
(\mathrm{p}-\text {-value })\end{array}$ & test & 0.167 & 0.265 & 0.148 & 0.108 & 0.183 & 0.094 & 0.782 & 0.650 & 0.661 \\
\hline $\begin{array}{l}\text { Sargan } \\
(\mathrm{p}-\text {-value })\end{array}$ & test & 0.998 & 0.718 & 0.991 & 0.500 & 0.147 & 0.512 & 0.971 & 0.300 & 0.936 \\
\hline
\end{tabular}

*** The significance levels at the $1 \%$.

** The significance levels at the $5 \%$.

* The significance levels at the $10 \%$.

Source: calculated by the author

Information from Table 1 show that the results of Wald test ( $\mathrm{F}$ test) in all three cases for all three variables representing capital structure have $\mathrm{P}_{\text {value }}=0.000<1 \%$, therefore, there is enough conditions to reject the null hypothesis $\mathrm{H}_{0}$ (the beta coefficients of the independent variables are 0 ) at significance levels of $1 \%$. This means that regression models via two-step GMM have significance in explaining the impact on dependent variables. Besides, Arellano-Bond test result for the second-order autocorrelation as well as Sargan test result for overidentified restrictions for all cases have $\mathrm{P}_{\text {value }}>5 \%$. So, the models are determined to be consistent.

Regarding examination of determinants of firms' capital structure, at the 5\% significance level, the capital structure of listed joint stock corporations in Vietnam is positively affected by only SIZE, PROFIT, LIQUID variables among six ones representing companies' characteristics. This means that those enterprises tend to increase their debts when their business size, profitability, and current payment capacity raise. Nonetheless, all three factors have influence on two among three variables describing capital structure. Namely, the size of the firm positively impacts on the percentage of total debts and the ratio of long-term debt; profitability has positive effect on long-term and short-term debt rate; payment capacity affects total debts ratio and short-term debt ratio positively. On the level of influence, company's size has the highest peta coefficient which illustrates the affectation on capital structure (fluctuating around $1 \%$ ), the lower value belongs to profitability (about $0.1 \%$ ), and payment capacity possesses an extremely low grade (nearly 0 ). In contrast, test results at the 5\% significance level prove that there is no evidence that GROW, TANG, and RISK have impact on capital structure. Moreover, at a very low significance level of 1\%, the one-lagged of dependent variable $\left(\mathrm{D}_{\mathrm{i}, \mathrm{t}-1}\right)$ is tested to have impression on all three proxies which define firms' capital structure. This also shows that the joint stock companies in Vietnam often plan current capital structure in accordance with capital structure in the previous year, so its volatility is often not high.

In terms of elements that display macroeconomic conditions, test results prove that current corporate income tax rate (TAX) and inflation rate (INF) affect capital structure at a significance level at $10 \%$ whereas economic growth (GROW) and interest rate (IR) do not. In detail, corporate income tax rate and long-term debt ratio have adverse influence. In other words, the Vietnamese companies have a reduced tendency long-term debt rate when corporate income tax rate rises. This trend is found out in some studies of Booth et al. (2001), Biger et al. (2008), Bostos et al. (2009), Handoo and Sharma (2014) abroad, or of Dang Thi Quynh Anh and Quach Thi Hai Yen (2014), Vo Thi Thuy Anh et al. (2014) in Vietnam. Additionally, the inflation rate is determined to have positive influence on total debts rate. Therefore, during the period of 2008-2015, non-financial joint stock enterprises in Vietnam tended to raise their debts in line with inflation's increase. Indeed, a growth in inflation makes real interest rate decline, leading companies to borrow more (Camara, 2012; Yang et al., 2015).

Besides, two out of three indicators concerning financial development as financial size (FD2) and financial efficiency (FD3) exist statistically significant in the impact on capital structure at the 5\% significance level. This is the same meaning with the fact that remainder indicator (FD1) has not statistically significant in this relationship. It also proves that companies in Vietnam prefer mobilizing debt via intermediate channels, especially commercial banks, to using stock exchange. It derives from the huge difference between two kinds of channels for capital mobilization. The companies have to face tight guarantee conditions as well as limited demand of the market for corporate bonds when issuing more bonds for debt on the stock market; meanwhile, binds are mainly based on collateral if the companies want to borrow from the bank. This variety obviously causes the main borrowing trend via intermediate channels of Vietnamese firms. On the other hand, the adverse effect of financial size (FD2) on capital structure 
supplies an evidence that the limited size of stock market in comparison with commercial banks, making a negative impact on the trend of enterprises' borrowing. Lastly, it is recognized that financial efficiency (FD3) variable has statistically significant. It means that the effective performance of financial market will motivate companies to enhance more external debts.

Similar to financial development variables, there are two in three variables having the relationship with institutional quality are tested to affect capital structure. They are Control of Corruption (CORR) and Regulatory Quality (REGUL). In which, Regulatory quality has positive influence at the $1 \%$ significance level while Control of corruption is opposite at very high significance level at $10 \%$. As a result, the impact tendency of the latter has not high reliability.

In brief, the financial development and institutional quality improvement in Vietnam have partly supported and motivated the companies to access more external funds. Since the economic renovation in 1986, Vietnamese Government has made great efforts to develop financial activities such as forming stock exchanges, establishing private commercial joint stock banks with domestic and foreign capital, implementing more flexible management policies for the operation of commercial banks, etc. Concurrently, the institutional environment has also been better like strengthening anti-corruption, reforming administrative procedures, promulgating, and revising appropriate legal provisions to support the operation of enterprises, etc. It is a pity that but the results of this study show that both kinds of those activities are not really effective and have not really affected the companies' financial decisions yet.

\section{Conclusion}

After using the two-step system GMM to analyze the data from 464 non-financial listed joint stock companies on the greatest Vietnamese stock exchanges (HOSE, HNX, and UPCOM) as well as national data from 2008 to 2015, some main points can be retrieved as follows.

Macroeconomic conditions, financial development, and institutional quality, which are three groups in the group of variables reflecting business environment, have influence on capital structure of above firms through testing. Namely, in the first group, corporate income tax rate has negative impact but inflation rate is contradictory. By contrast, research results do not supply any proofs of the affectation of economic growth and interest rate on capital structure. For the second group, all variables have significance in the link with capital structure, but financial activity. In which, financial size owns negative impact on capital structure, on the opposite side of financial efficiency. The third group which describes institutional quality in Vietnam also has diverse findings. Regulatory quality affects capital structure positively at the $1 \%$ significance level meanwhile it is unclear for the conflict effect of Control of corruption at the $10 \%$ significance level.

In addition, the capital structure decision in Vietnamese joint stock firms is greatly affected by company characteristics as size, profitability, payment capacity. Furthermore, it is impacted by it itself of the previous year. Those results are relatively suitable for other Vietnamese and foreign studies.

\section{References}

Arellano, M., \& Bover, O. (1995). Another Look at the Instrumental Variable Estimation of Error-Components Models. Journal of Econometrics, 68, 29-51. https://doi.org/10.1016/0304-4076(94)01642-D

Bastos, D. D., Nakamura, W. T., \& Basso L. F. C. (2009). Determinants of Capital Structure of Publicly-Traded Companies in Latin America: The Role of Institutional and Macroeconomics Factors. Journal of International Finance and Economics, 9(3), 24-39.

Belkhir, M., Maghyereh, A., \& Awartani B. (2016). Institutions and corporate capital structure in the MENA region. Emerging Markets Review, 26, 99-129. https://doi.org/10.1016/j.ememar.2016.01.001

Biger, N., Nguyen, N. V., \& Hoang, Q. X. (2008). The determinants of capital structure: evidence from Vietnam. Asia-Pacific Financial Markets: Integration, Innovation and Challenges International Finance Review, 8, 307326. https://doi.org/10.1016/S1569-3767(07)00015-5

Blundell, R., \& Bond, S. (1998). Initial Conditions and Moment Restrictions in Dynamic Panel Data Models. Journal of Econometrics, 87, 115-143. https://doi.org/10.1016/S0304-4076(98)00009-8

Bokpin, G. A. (2009). Macroeconomic development and capital structure decisions of firms: evidence from emerging market economies. Studies in economics and finance, 26(2), 129-142. https://doi.org/10.1108/10867370910963055 
Booth, L., Aivazian, V., Demirguc-Kunt, A., \& Maksimovic, V. (2001). Capital structure in developing countries. Journal of Finance, 56, 87-130. https://doi.org/10.1111/0022-1082.00320

Camara, O. (2012). Capital structure adjustment speed and macroeconomic conditions: U.S. MNCs and DCs. International research journal of finance and economics, 84, 106-120.

Chakraborty, I. (2010). Capital structure in an emerging stock market: The case of India. Research in International Business and Finance, 24: 295-314. https://doi.org/10.1016/j.ribaf.2010.02.001

Dang, Thi Quynh Anh, \& Quach, Thi Hai Yen. (2014). The determinants of capital structure for listed enterprises on the Ho Chi Minh Stock Exchange (HOSE). Journal of Development and Integration, 18 (28), 34-39.

Deesomsak, R., Paudyal, K., \& Pescetto, G. (2004). The determinants of capital structure: evidence from the Asia Pacific region. Journal of Multinational Financial Management, 14, 387-405. https://doi.org/10.1016/j.mulfin.2004.03.001

Fama, E.F., \& French, K.R. (2002). Testing trade off and pecking order predictions about dividends and debt. The Review of Financial Studies, 15, 1-33. https://doi.org/10.1093/rfs/15.1.1

Graham, J. R., \& Harvey, C. R. (2001). The theory and practice of corporate finance: Evidence from the field. Journal of Financial Economics, 60, 187-243. https://doi.org/10.1016/S0304-405X(01)00044-7

Handoo, A., \& Sharma, K. (2014). A study on determinants of capital structure in India. IIMB Management Review, 26, 170-182. https://doi.org/10.1016/j.iimb.2014.07.009

Jensen, M. (1986). Agency costs of free cash flow, corporate finance, and takeovers. American Economic Review, 76, 323-329.

Jensen, M., \& Meckling, W. (1976). Theory of the firm: managerial behavior, agency costs and capital structure. Journal of Financial Economics, 3, 305-360. https://doi.org/10.1016/0304-405X(76)90026-X

Kayhan, A., \& Titman, S. (2007). Firms' histories and their capital structures. Journal of Financial Economics, 83 (1), 1-32. https://doi.org/10.1016/j.jfineco.2005.10.007

Kayo, E.K., \& Kimura, H. (2011). Hierarchical determinants of capital structure. Journal of Banking and Finance, 35, 358-371. https://doi.org/10.1016/j.jbankfin.2010.08.015

Kraus, A., \& Litzenberger, R.H. (1973). A State-Preference Model of Optimal Financial Leverage. Journal of Finance, 28, 911-922. https://doi.org/10.1111/j.1540-6261.1973.tb01415.x

Le, Dat Chi. (2013). The determinants of planning financial structure of financial managers in Vietnam. Journal of Development and Integration, 9 (19), 22-28

Memona, P. A., Rusb, R., \& Ghazalic, Z. (2015). Firm and Macroeconomic Determinants of Debt: Pakistan Evidence. Procedia - Social and Behavioral Sciences, $172, \quad 200$ - 207. https://doi.org/10.1016/j.sbspro.2015.01.355

Michaelas, N., Chittenden, F., \& Poutziour, P. (1999). Financial Policy and Capital Structure Choice in U.K. SMEs: Empirical Evidence from Company Panel Data. Small Business Economics, 12(2), 113-130. https://doi.org/10.1023/A:1008010724051

Modigliani, F., \& Miller, M. (1958). The cost of capital, corporation finance, and the theory of investment. American Economic Review, 48(3), 261-297.

Modigliani, F., \& Miller, M. (1963). Corporate income taxes and the cost of capital, a correction. American Economic Review, 53(3), 433-443.

Mokhovaa, N., \& Zinecker, M. (2014). Macroeconomic factors and corporate capital structure. Procedia - Social and Behavioral Sciences, 110, 530 - 540. https://doi.org/10.1016/j.sbspro.2013.12.897

Myers, S., \& N. Majluf. (1984). Corporate Financing and Investment Decisions when Firms have Information that Investors do not have. Journal of Financial Economics 13, 187-221. https://doi.org/10.1016/0304-405X(84)90023-0

Myers, S.C. (1984). The capital structure puzzle. Journal of Finance. 39, 575-592. https://doi.org/10.2307/2327916

Nguyen, Thanh Cuong, \& Nguyen, Hong Thang. (2015). Firm Characteristics and Capital structure Decision: Evidence from Seafood Processing Enterprises in the South Central Region of Vietnam. Research Journal of Finance and Accounting, 6(8), 69-84. 
Nguyen, Thi Canh, \& Nguyen, Thanh Cuong. (2011). The determinants of capital structure for Vietnam's seafood processing enterprise. Science and Technology Development, 14(Q1), 28-54.

Ozkan, A. (2001). Determinants of capital structure and adjustment to long run target: evidence from UK company panel data. Journal of Business Finance and Accounting, 28, 175-198. https://doi.org/10.1111/1468-5957.00370

Oztekin, O., \& Flannery, M.J. (2012). Institutional determinants of capital structure adjustment speeds. Journal of Financial Economics, 103, 88-112. https://doi.org/10.1016/j.jfineco.2011.08.014

Pham, Tien Minh, \& Nguyen, Tien Dung. (2015). The determinants of capital structure from static to dynamic model: Research in real estate sector in Vietnam. Journal of Economic Development, 26(6), 58-74.

Phan Thi Bich Nguyet (2011). The impact of the income tax system on capital structure of Vietnamese joint stock companies. Journal of Economic Development, 247, 23-30.

Rajan, R., \& Zingales, L. (1995). What do we know about capital structure? Some evidence from international data. Journal of Finance. 50, 1421-1460. https://doi.org/10.1111/j.1540-6261.1995.tb05184.x

Temimi, A., Zeitun R., \& Mimouni, K. (2016). How does the tax status of the country impact capital structure? Evidence from the GCC region. Journal of Multinational Financial Management, 37-38, 71-89. https://doi.org/10.1016/j.mulfin.2016.08.002

Titman, S., \& Wessels, R. (1988). The determinants of capital structure choice. Journal of Finance, 43(1), 1-19. https://doi.org/10.1111/j.1540-6261.1988.tb02585.x

Truong, Hong Trinh, \& Nguyen, Thao Phuong. (2016). Effects of Financial Crisis on Capital Structure of Listed Firms in Vietnam. International Journal of Financial Research, 7(1), 66-74.

Vo, Thi Thuy Anh, Tran, Khanh Ly, Le, Thi Nguyet Anh, Tran, \& Thi Dung. (2014). Studying the impact of macro factors on capital structure of listed companies on the Vietnamese stock market. Journal of Economics and Development, 207, 19-27.

Vu, Thi Ngoc Lan, \& Nguyen, Tien Dung. (2013). The determinants of capital structure of enterprises in Vietnam Oil and Gas Group. Journal of Economics and Development, 193, 23-28.

Wald, J. K. (1999). How firm characteristics affect capital structure: an international comparison. The Journal of Financial Research, 12(2), 161-18. https://doi.org/10.1111/j.1475-6803.1999.tb00721.x

Yang, Y., Albaity, M., \& Hassan, C. H. B. (2015). Dynamic capital structure in China: determinants and adjustment speed. Investment Management and Financial Innovations, 12(2), 195-204. 